\title{
COSYREL ${ }^{\oplus}$ - jedna fixní kombinace - rozmanité využití v praxi
}

\section{Zdeněk Coufal}

Kardiologické oddělení, Krajská nemocnice T. Bati, a.s., Zlín

Inhibitory ACE a betablokátory mají své nezastupitelné místo v kardiologii v různých indikacích - v léčbě hypertenze, srdečního selhání, v sekundární prevenci u nemocných s ischemickou chorobou srdeční, především po infarktu myokardu či koronární intervenci. Mohou však být úspěšně použity i v jiných indikacích. Prognózu kardiologicky nemocných lze ovlivňovat na několika různých úrovních a tomu odpovídá bohužel i větší množství užívaných léků. V posledních letech sledujeme trendy, že výrobci léků přicházejí na trh s fixními kombinacemi dvou nebo tří vzájemně se doplňujících léků v jedné tabletě. Jedna z nich - fixní kombinace betablokátoru a ACE inhibitoru - je však jedinečná a jmenuje se COSYREL ${ }^{\oplus}$.

Klíčová slova: ACE inhibitory, betablokátory, hypertenze, srdeční selhání, akutní koronární syndrom, Cosyrel.

\section{COSYREL ${ }^{\oplus}$ - one fixed combination, multiple use in treatment}

ACE inhibitors and beta-blocking agents have an irreplaceable role in various indications in cardiology, including hypertension, heart failure, secondary prevention in coronary heart disease, especially after acute coronary syndromes. They can be successfully used in other indications, too. Patient prognosis can be influenced at various levels, which however means higher numbers of drugs used. In recent years, we have witnessed trends in drug manufacturers to bring to the market pills with two or three complementary substances. One of them - a fixed combination of a beta-blocking agent and an ACE inhibitor - is unique and its name is COSYREL ${ }^{\oplus}$.

Key words: ACE inhibitors, beta-blocking agents, hypertension, heart failure, acute coronary syndrome, Cosyrel.

\section{Indikační využití fixních kombinací}

Nejčastěji se s využitím fixních kombinací v kardiologii setkáváme v léčbě hypertenze. Fixní kombinace je výhodná z důvodů snížení počtu užívaných tablet a možnosti užití nižších dávek se synergním účinkem, což má za cíl snížit výskyt nežádoucích účinků. Tato tradice sahá až do 70. let minulého století, kdy na trh prišly první fixní kombinace antihypertenzivních prípravků. Z pohledu dnešních znalostí nebyly príliš povedené (např. prípravek Trimecryton obsahující krátkodobě působící betablokátor metipranolol, dlouhodobě působící diuretikum chlortalidon a centrálně pưsobící dihydroergocristin). Dnes je na trhu celá řada fixních kombinací inhibito- rů ACE (ACEi) či blokátorů AT2 receptorů (ARB, sartanů) s blokátory kalciových kanálů (CCB) a diuretiky. Velká variabilita kombinací dávek obsažených léků klade dưraz na trpělivou titraci léčby šité na míru (tailoring).

V léčbě srdečního selhání je opět základem léčby některýz preparátů ovlivňujicích renin-angiotenzin-aldosteronový systém (RAAS) (ACEI, ARB). K tomu přistupují v této indikaci dále betablokátory (BB) (1). Zde existuje jediná fixní kombinace, a to ACEI perindoprilu a betablokátoru bisoprololu v podobě preparátu COSYREL (2).

Pro sekundární prevenci u pacientů po akutní koronární príhodě (AKS) potřebuje nemocný ovlivnit hned několik úrovní - ACEI/ARB hrají roli $\checkmark$ prevenci remodelace levé komory (3), BB snižují riziko rekurence AKS (4), statiny snižují nejen koncentraci celkového a LDL-cholesterolu v krvi, ale také stabilizují aterosklerotické pláty, čímž opět snižují riziko rekurence AKS (3). Protidestičková léčba (kombinace kyseliny acetylsalicylové - ASA a dalšího protidestičkového léku, zpravidla P2Y 12 inhibitoru) (3) má za úkol snižit riziko opakování AKS zvláště v brzkých týdnech a měsících po AKS a po koronární intervenci. Zde bychom využili čtyři pětikombinační „polypill“. Má-li nemocný kromě koronární príhody další nemoci, je na polypragmazii „zaděláno“. V takovém prípadě je využívání fixních lékových kombinací velmi výhodné.

V následujících několika kazuistikách ukazujeme využití méně obvyklé výhodné fixní kombinace ACEI s BB v preparátu COSYREL ${ }^{\oplus}$. 
Obr. 1. Transtorakální echokardiografie

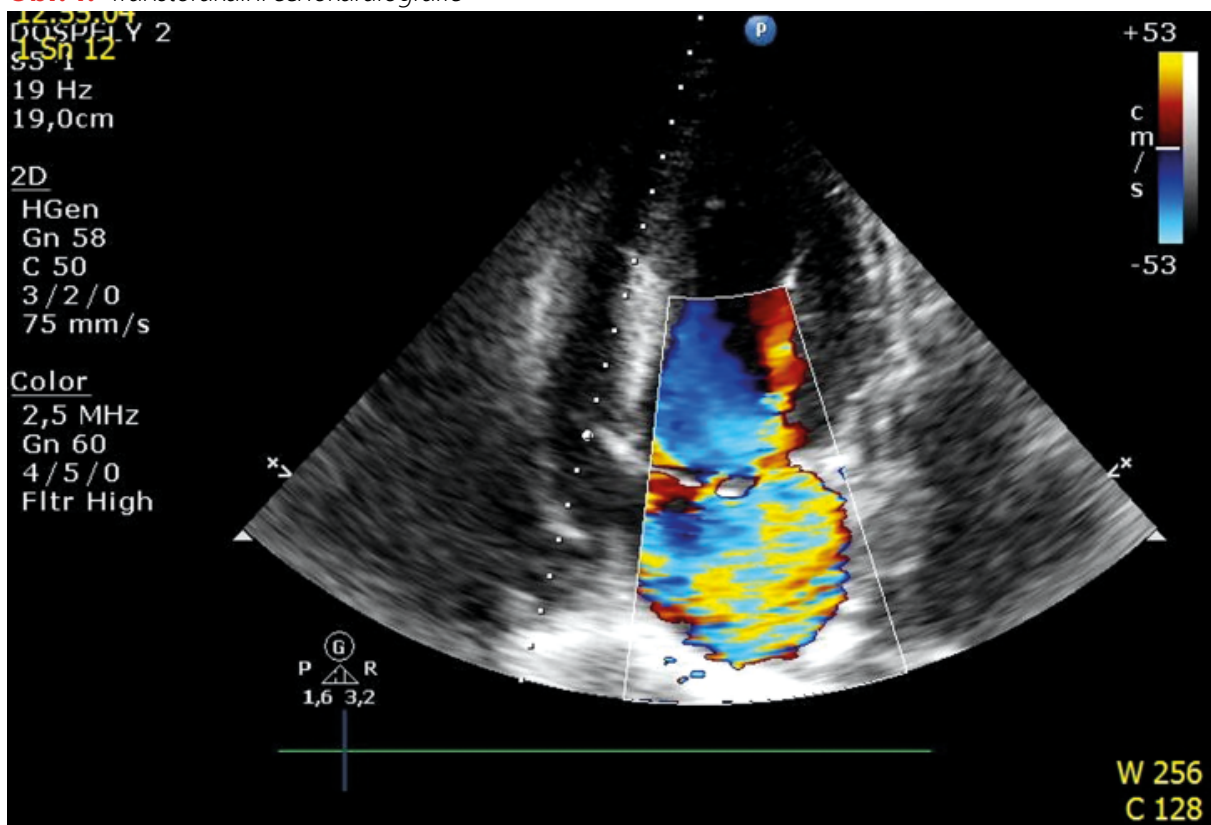

Obr. 2. Transesofageální echokardiografie

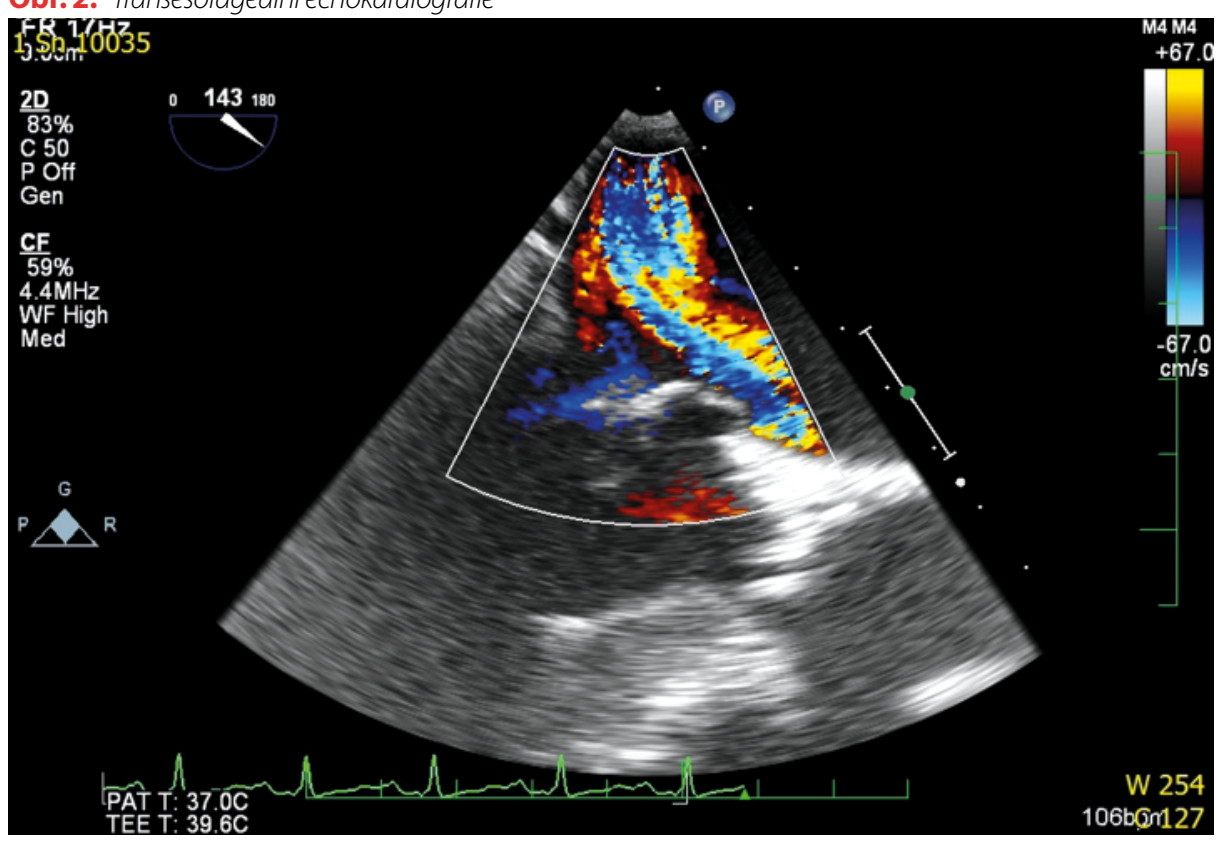

\section{$\operatorname{COSYREL}^{\circledR} \mathrm{v}$ léčbě ischemické choroby srdeční}

Muž, nar. 1947, byl ošetřen v našem kardiocentru v roce 2009 pro akutní infarkt přední stěny myokardu na podkladě uzávěru středního segmentu r. interventricularis anterior (RIA), který byl ošetřen primární PCl s implantací stentu, současně zjištěna kritická stenóza ve střední části r. circumflexus (RC), kterou jsme ošetřili ve druhé době. V okamžiku AKS nebyly u nemocného známy žádné rizikové faktory, průběh hospitalizace byl nekomplikovaný a muž byl propuštěn s léčbou Plavix 75 mg 1-0-0, Anopyrin 100 mg 0-1-0, Concor COR $5 \mathrm{mg}$ $1 / 2-0-0$, Prestarium NEO $5 \mathrm{mg} 1 / 2-0-0$, Sortis
20 mg 0-0-1. Po roce byl z léčby vypuštěn Plavix (klopidogrel). V roce 2017 vznikla potřeba zvýšit dávku perindoprilu z důvodu vzestupu krevního tlaku. O rok později jsme s výhodou využili tehdy již dostupného kombinovaného preparátu COSYRE ${ }^{\oplus}$ 5/5 namísto dvou léků Prestarium a Concor COR. Pacient zjednodušení léčby uvítal, nový lék dobře toleroval a uživá jej nadále. Při kontrole v roce 2020 jsme dokumentovali hodnoty TK 130/70 mmHg a TF 70/min, avšak vzestup LDL-cholesterolu na 2,48 mmol/l a zvýšili jsme dávku atorvastatinu (cílová hodnota LDL-cholesterolu v sekundární prevenci po infarktu myokardu je 1,4 mmol/l) s plánem další titrace léčby.
Muž, nar. 1951, s anamnézou hypertenze (léčen CCB Kapidin) byl akutně ošetřen v roce 2012 pro akutní infarkt myokardu přední stěny při kritické stenóze proximální části RIA ošetření pPCI s implantací stentu. Propuštěn s léčbou Anopyrin 100 mg 0-1-0 (trvale), Trombex 75 mg 1-0-0 (na 12 měsíců), Concor 5 mg 1/2-0-0, Prestarium NEO 5 mg 1/2-0-0, Sortis 40 mg 0-0-1. Do roku 2018 nebyla nutná změna léčby (kromě vysazení klopidogrelu po roce od infarktu). Při kontrole v roce 2018 (TK 140/84 mmHg, TF 65/min) jsme léčbu zjednodušili náhradou Concoru a Prestaria kombinovaným preparátem COSYREL ${ }^{\oplus} 5 / 5$ v ekvivalentní dávce $1 / 2$ tbl. denně, kterou pacient dobře toleruje a zůstává na ní doposud (poslední dokumentovaná hodnota TK 130/82 mmHg).

\section{COSYREL ${ }^{\circledR} v$ léčbě \\ srdečního selhání}

Muž, nar. 1944, s anamnézou hypertenze, diabetes mellitus, paroxysmální fibrilace síní, primární trombocytemie (léčen kombinací Converide 300/12,5 mg, Glyclada 30 mg, Tromboreduction, Milurit, Warfarin, Omnic) byl ošetřen v naší kardiologické ambulanci v únoru 2020 pro postupné narůstání námahové dušnosti. Konstatovali jsme neuspokojivou kompenzaci hypertenze (TK 170/100 mmHg), sinusový rytmus, echokardiograficky hraniční hypertrofii mezikomorového septa, mírně sníženou ejekční frakci levé komory (45\%), dilataci levé síně (52 mm), diastolickou dysfunkci. Hodnota NT-pro-BNP 3570 ng/l doplňovala klinický obraz srdečního selhání. Kombinaci irbesartanu s hydrochlorotiazidem (Converide 300/12,5 mg) jsme nahradili kombinovaným lékem COSYREL ${ }^{\circledast}$ 5/10 mg (5 mg bisoprololu a $10 \mathrm{mg}$ perindoprilu) spolu s kličkovým diuretikem Furon 40 mg denně a spironolaktonem (Verospiron) 25 mg denně. EKG Holter při této léčbě dokumentuje průměrnou TF 78/min, občasné krátkodobé paroxysmy fibrilace síní s TF do 140/min. Při kontrole po měsíci léčby udává nemocný výrazné zlepšení dechu, došlo ke zlepšení TK na hodnotu 140/80 mmHg. Léčbu jsme upravili na dávku COSYREL ${ }^{\oplus}$ 10/10 mg a snízili dávku furosemidu. Při této léčbě dokumentujeme úplnou normalizaci hodnot TK, na EKG Holteru snížení výskytu paroxysmů fibrilace síní a navíc v případě krátkodobých výskytů fibrilace síní je průměrná frekvence komor maximálně 110/min. Nemocný je nyní ve funkční třídě NYHA I.

Muž, nar. 1969, byl v únoru 2017 přeložen do našeho kardiocentra ze spádového interního 


\section{Obr. 3. Aortografie}

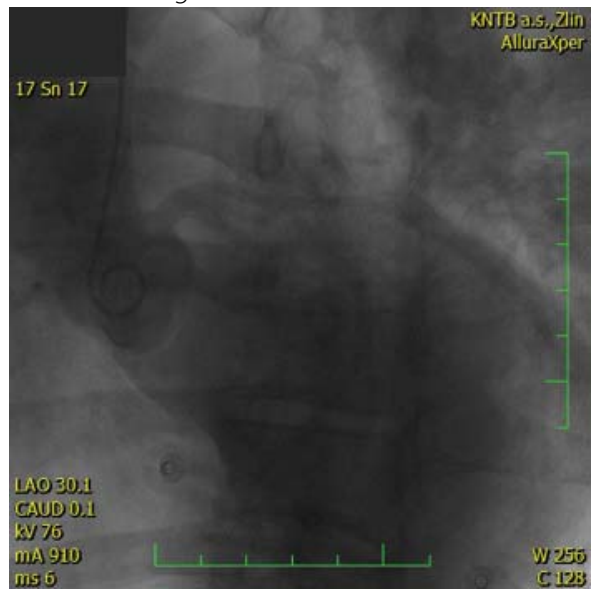

oddělení, kam byl přijat pro akutní srdeční selhání s mírnou elevací troponinu I (142 ng/l), středně těžkou depresí systolické funkce LK (30\%). Diferenciálně diagnosticky přicházela do úvahy dilatační kardiomyopatie nebo pozánětlivá KMP. Koronarograficky jsme neprokázali ischemickou prričinu dysfunkce LK, cMRI nalezeny okrsky LGE ve stěně LK v obl. septa a patrně ještě i v apikální polovině však srdce ventrolaterálně, v mezokardiální lokalizaci, což svědčí pro neischemickou etiologii jizevnatých změn. Nemocný nastaven na léčbu srdečního selhání: Prestarium 5 mg, Concor COR 2,5 mg, Furon $40 \mathrm{mg}$. $V$ dalším průběhu jsme titrovali léčbu - přidán Verospiron, navyšována dávka Concor COR, na konci roku 2017 byla léčba zjednodušena na COSYREL ${ }^{\oplus}$ 10/5 (TK 130/80 mmHg, TF 55/ min), Furon 40 mg, Verospiron 25 mg. V ř rijnu 2017 byl pacientovi implantován jednodutinový ICD z primárně preventivní indikace. V lednu 2018 bylo nutno pro zhoršenífunkční zdatnosti navýšit dávku diuretik s následnou stabilizací. V červenci 2018 ve stabilizovaném stavu vysazen COSYREL ${ }^{\oplus}$, nasazen sólo betablokátor bisoprolol (Concor COR 5 mg), namísto Verospironu pro nežádoucí účinky (mastodynie) nasazen Eplerenon a po dvoudenní pauze od vysazení COSYRELu začal užívat sacubitril/valsartan (Entresto ${ }^{\circledast}$ 24/26mg 2× denně). Po měsíci navýšena dávka Entresto na 49/51 mg 2× denně. Při kontrole v ř́jnu 2018 však nemocný informuje, že se mu po navýšení dávky Entresto začala točit hlava, bylo mu na zvracení, u praktického lékaře

\section{LITERATURA}

1. Špinar J, et al. Summary of the 2016 ESC Guidelines on the diagnosis and treatment of acute and chronic heart failure. Prepared by the Czech Society of Cardiology. Cor Vasa 2016; 58: e530-e568. http://www.sciencedirect.com/science/article/pii/S0010865016300996.

2. Jediná fixní kombinace BB + ACEi = léty ověřená účinnost měl údajně vysoký tlak (TKs 180 mmHg), takže se bez konzultace kardiologa vrátili k původní medikaci COSYREL 10/5 mg + Verospiron 25 mg. Pacient současně opět reklamuje bolesti a svědění bradavek. Verospiron jsme opět vyměnili za Eplerenon, COSYRE ${ }^{\oplus}{ }^{10 / 5}$ mg jsme ponechali. S touto terapií je nyní nemocný spokojený, stabilizovaný.

\section{COSYREL ${ }^{\circledR} \mathbf{v}$ léčbě aortální regurgitace}

Muž, nar. 1975, bez jakýchkoli nemocí, v předchorobí byl akutně ošetřen v dubnu 2018 pro náhle vzniklou dušnost, schvácenost, tachypnoi, desaturaci $\mathrm{SpO}_{2} 80 \%$, klinický nález odpovídající plicnímu edému, TK akutně 220/110 mmHg. Lékař urgentního př́ijmu zhodnotil stav jako plicní edém při hypertenzní krizi. Pacient byl napojen na neinvazivní ventilaci, podána diuretika a kontinuální infuze Isoketu. Echokardiograficky jsme překvapivě zjistili dilataci a hypertrofii levé komory, hyperkinetickou cirkulaci (EF LK 70-75\%), bikuspidní aortální chlopeň se středně těžkou stenózou a významnou regurgitaci a jako prričinu plicního edému parciální rupturu závěsného aparátu předního cípu mitrální chlopně s prolapsem a významnou regurgitací (obrázky 1, 2, 3). Nemocný byl následujícího dne přeložen na kardiochirurgické pracoviště, kde byla provedena náhrada aortální chlopně mechanickou protézou, plastika mitrální chlopně, pooperačně AVB I.st., PQ 280 ms, nastaven na Warfarin s cílovou hodnocou INR 2-3, Concor 5 mg 1-0-0, Prestarium Forte $10 \mathrm{mg} 1-0-0$, Verospiron $25 \mathrm{mg}$ 0-1-0, Controloc 20 mg 1-0-0. V dalším průběhu dochází k postupné normalizaci velikosti levé komory, upravují se převodní parametry na EKG (PQ 180 ms). O půl roku později vysazujeme Verospiron a Controloc, namísto Concoru s Prestariem nasazujeme fixní kombinaci COSYREL ${ }^{\oplus}$ 5/10 mg.

V řijnu 2019 dokumentujeme neuspokojivou kontrolu hypertenze (TK 158/100 mmHg, TF 61/ min). Uvažujeme o zvýšení dávky Cosyrelu na 10/10 mg, avšak z obavy z možnosti opětovného prodloužení AV vedení (aktuálně stále $180 \mathrm{~ms}$ ) a zpomalení TF pod 60/min volíme přidání amlodipinu v dávce $5 \mathrm{mg}$. Při této léčbě měl nemocný

směřující k lepší compliance. [Online] Medicína po promoci 1/2017. [Citace: 20. 06 2020]. https://www.tribune.cz/clanek/41715-jedina-fixni-kombinace-bb-acei-lety-overena-ucinnost-smerujici-k-lepsi-compliance.

3. Oštádal P, Táborský M, Linhart A, et al. Stručný souhrn doporučení pro dlouhodobou péči o nemocné po infarktu v lednu 2020 TK 130/80 mmHg, TF 58/min, echokardiograficky zůstává koncentrická hypertrofie LK s dobrou systolickou funkcí (EFLK 61 \%), pacient má normální funkční zdatnost (NYHA I), opět zvládá kondiční tréning (chůze, běh, plavání).

\section{COSYREL ${ }^{\circledR}$ v léčbě hypertenze}

Žena, nar. 1975, byla prvně ošetřena v řijnu 2018, palpitace a vyššíTK (150/95 mmHg) v souvislosti s respiračním infektem. Při vyšetření měla TK 150/100 mmHg, echokardiograficky bez průkazu hypertrofie LK, na EKG byla prítomna sinusová tachykardie 100/min. Doporučili jsme kontrolu TK Holterem po přeléčení respiračního infektu, kde jsme dokumentovali normální hodnoty TK (24hodinový průměr 127/78 mmHg s nočním dipem). Nemocná byla ponechána bez léčby. V listopadu 2019 přichází znovu pro tlak v hlavě, zpomalení, zhoršení pozornosti, třes. Při domácím měření naměřen tlak 160/95 mmHg. Na EKG opět sklon k tachykardii (96/min). Tentokrát jsme zahájili léčbu malou dávkou betablokátoru (Betaloc ZOK $25 \mathrm{mg}$ ). Kontrolní TK Holter při této léčbě však prokazuje během dne 39\% hodnot TKs a $41 \%$ TKd nad doporučenou limitní hodnotou, proto jsme přistoupili ke kombinační léčbě COSYREL ${ }^{\oplus}$ $5 / 5$ mg v dávce $1 / 2$ tbl. denně, která následně titrována na dávku 1 tbl. (tj. 5/5 mg) denně s velmi dobrým efektem a dobrou subjektivní tolerancí.

\section{Závěr}

Kombinační léčba má v kardiologii své opodstatnění, umožňuje optimalizaci terapie s minimalizací vedlejších účinků oproti vysokým dávkám monoterapie. Fixní kombinace betablokátoru bisoprololu a ACE inhibitoru perindoprilu má široké indikační spektrum, díky čtyřem silám (5/5 mg, 5/10 mg, 10/5 mg a 10/10 mg) umožňuje individualizovat a titrovat léčbu na míru konkrétním pacientům (tailoring). Prípravek je nemocnými dobře tolerován. Uvedené kazuistiky potvrzují jeho široké indikační možnosti. Využití fixní kombinace v léčbě snižuje počet užívaných tablet a zlepšuje tak adherenci nemocných k léčbě.

myokardu. Cor Vasa 2019: 61, 2019: e471-e480. 4. Law MR, Morris JK, Wald NJ. Use of blood pressure lowering drugs in the prevention of cardiovascular disease: metaanalysis of 147 randomised trials in the context of expectations from prospective epidemiological studies. BMJ 2009; 338: b 1665. 